Coumarane from $\beta$-Bromo-ethyl-phenyl Ether.-The $\beta$-bromo-ethyl phenyl ether is prepared by treating sodium phenolate with an excess of ethylene bromide, following the method of Weddige. ${ }^{1}$ On treating this with $1 / 10$ of its weight of zinc chloride, the reaction is not so vigorous as in the analogous formation of chromane and two hours' heating is necessary. The product may then be distilled directly in $30-40 \%$ yields.

URBANA, ILLINOIS.

[CONTRIBUtTon FROM THE Chemical Research LABORATORY, the UPJOHN COMPANY.]

\title{
THE PROTEIN EXTRACT OF RAGWEED POLLEN.
}

BX FREDERICK W. HEXL.

Received January 16, 1919.

In a previous communication ${ }^{2}$ from this laboratory the proximate analysis of ragweed pollen was reported. The distribution of the nitrogen was particularly sought in order to have more precise information con.cerning the proper quantitative composition of pollen antigen, as required for immunization work. It became apparent at once that a very considerable quantity of nonprotein nitrogen was present, and in view of the possibility of an active base being present the investigation was extended for the purpose of isolating not only the proteins but also these bases.

The presence of agmantin which was found may have some bearing on the hay fever problem because of the possibility of a similarity which it may possess with $\beta$-iminazolylethylamine. The latter is known to produce asphyxia in guinea pigs with anaphylactic shock. This similarity is quite doubtful however, and the nature of the hexone bases isolated does not cause the protein fraction to appear less incriminated in the production of hay fever. The preparation of protein antigen as usually conducted appears entirely rational. In the opinion of the writer it remains for some large hay fever clinic to test out the various proteins, especially the proteose, and determine which of them may be responsible for hay fever. This proteose is unstable and becomes insoluble on preserving so that a very close coopperation must exist between the clinicians and those doing the chemical work. The writer intends to analyse by the Van Slyke method the preparations herein described, and regrets the insurmountable difficulties which have prevented the satisfactory clinical study of the products obtained.

Kamman ${ }^{3}$ holds the view that the substance (toxin) which produces the peculiar pollen reaction, $e . g$., the ophthalmic reaction, is not due to the albumin itself, but to a closely associated substance. This is paral-

I. prakt. Chem., [2] 24, 242 (188r).

2 Trris Journal, 39, , 470 (x9r7).

a Biochem. Z., 46, 55 (1912). 
leled by the view that the albumin ricin of the castor seed is not toxic, but that in preparing ricin, the toxin is a synchronously separated non. protein substance. If this is true we pass from a subject amenable to chemical investigation to one allied to enzymes. Osborne, Mendel and Harris consider the toxic agent of castor beans to be the albumin itself. The remarkably high toxicity of the albumin, $0.05 \mathrm{I}$ g. per kilo, seems to exclude the possibility of an associated substance. In the case of ragweed pollen albumin it is important to remark that we were obliged to remove to the hospital a hay fever subject who received a saline extract of $0.00033 \mathrm{~g}$. pollen, equivalent to about $0.057 \mathrm{~g}$. albumin, because of the very severe reaction produced. If this is produced by a toxin associated with the albumin, the subject passes beyond the reach of our present methods of chemical investigation.

The enzymes of the pollen cell, in so far as they are extracted are probably associated with the protein. The writer intends to study this subject. Kamman subjected his precipitated albumin to autolysis at a low temperature for 8 days, and he claims that the longer the digestion proceeded the more active his end-products becane. A substance thus produced, which no longer gave the Millon or the Molisch reaction, is stated to be roo times more active than the crude albumin. In this work then, we observe a return to the methods used by Müller, Jacoby and Brieger who unsuccessfully attempted to prove the non-protein nature of ricin by subjecting the protein to tryptic digestion in the hope of observing no diminution in the toxicity of the end-products.

It is worth while calling attention to the fact that while the immunological consideration of this subject involves a very voluminous literature describing the use of many different antigens and mixed antigens as well as other considerations caused by the presence of enzymes in the antigen, we are still quite ignorant of the simplest chemical information concerning ragweed pollen. In a general way the same may be said of a vast majority of antigens.

A further and perhaps greater biological interest is attached to the ragweed pollen grain, because it gives rise to the two sperm nuclei. Since Kresling's ${ }^{2}$ paper on the pollen of Pinus sylvestris appeared the methods of chemical investigation have been so developed that we may now make a close comparison of the contents of the pollen "cell," with that of the spermatozoa.

The popular misconception of pollen as the male element, has caused some to compare the pollen grain directly to the spermatozoa. Thus in the text-book of Haas and Hill, it is suggested that protamines might be found in pollen. The initial pollen grain however undergoes a further

1 Am. J. Physiol., 14, 259 (rgos).

2 Arch. Pharm, 220, 389 (1891). 
development before producing the two cells which are homologous to the spermatozoa.

Botanically, the contents of the pollen cell is the male gametophyte, or male plant whose function is to produce the sperms. This it proceeds to do in most cases shortly prior to pollination.

The pollen begins to germinate on the stigma soon after pollination by projecting through its outer wall (exine) the so-called "pollen tube." The pollen tube is formed by the extension of the inner wall of the pollen grain (intine) through the exine by enzymatic action. The function of this tube which makes its way through the style is to carry the sperm nuclei to fertilize the egg nucleus. During this period the cell probably reorganizes its constituents for fertilization. The cell as it leaves the anther is probably quite differently constituted than later at the time of fertilization. If now we consider that the process of fertilization in this case shotild proceed along similar chemical paths with those which have been studied in the animal kingdom, and reason by analogy to the spermatozoa of fishes for example, we would consider that these male nuciei to be developed by the pollen tube would require the presence of protamine and nucleic acid.

The present investigation was begun by extracting the thick outer wall (exine) with ether and then with alcohol. This still leaves a thinner inner wall (intine) which is made up chiefly of cellulose. These walls together constitute $65 \%$ of the structure, so that in discussing the pollen protein fraction from I $50 \mathrm{~g}$. material, we have in reality examined the water-soluble constituents of approximately $400 \mathrm{~g}$. of the cell contents. The aqueous extract contains a coagulable albumin (1.2-1.5\%) and a mixture of proteoses $(3.0 \%)$. The filtrate however after a complete salting out of these products still contains a large proportion of the nitrogen. When now this solution is examined, a quantity of peptone is precipitated with basic lead acetate and we find in the filtrate a number of simpler chenical molecules (building stones) with which the pollen might build up during the development of the pollen tube a number of substances required for the sperm nuclei, if it is to parallel the spermatozoa of the fish. The hexone bases, arginine, histidine, and lysine are abundantly present. Arginin which should form the chief building stone for protamin is strangely enough present in the smallest proportion. The presence of guanidino-butylamine (decarboxylated arginine) previously found by Kosse $1^{1}$ by heating herring spawn with $5 \%$ sulfuric acid at 4 atmospheres, and by Engeland and Kutscher ${ }^{2}$ in ergot indicates a possible source of a further supply of arginine.

1Z. physiot. Chem., 66, 257 (19ro).

"Centr. Physiol., 24, 479 (1910). 
If a nucleic acid similar to that described by Osborne and Harris ${ }^{1}$ from the embryo of the wheat is to be synthetized in the sperm nuclei in the pollen tube, I am at a loss to find how this is to be accomplished. There is only a minute quantity of organic phosphorus in pollen and this is present in a lecithin, which has been isolated from the alcoholic extract. Of purine bases, adenine was found in quantity. In this connection the well known occurrence in pollens of the nucleoside guanosine ${ }^{2}$ is interesting. Some unsatisfactory evidence of the presence of this substance was adduced.

After completing the water extraction of the ragweed pollen, it was found that the chief protein constituent could be extracted with dilute alkalies, and a fine preparation of a uniform glutelin could be rather easily prepared. It amounted to $2.9 \%$. At the end ot this paper a summary of the nitrogenous constituents isolated will be found.

A later paper will discuss the ether and alcoholic extracts of ragweed pollen.

\section{Experimental Part.}

First Protein Extraction.-A collection of ragweed pollen amounting to about $448 \mathrm{~g}$. (moisture $=5 \%$ ) was exhaustively macerated with ether, thus removing the fat. This residue was then exhaustively percolated with cold $95 \%$ alcohol.

The residue was air dried and then passed through a roo-mesh sieve. It weighed approximately $349 \mathrm{~g}$., indicating that about $100 \mathrm{~g}$. had been extracted. It was used to study the protein constituents. For this purpose an aliquot of $2 \%, i . e ., 7.0 \mathrm{~g}$. was taken. This is equivalent to $8.96 \mathrm{~g}$. of the original pollen. A complete quantitative study gave the following results:

Ether and alcohol extracted pollen 7.0 g. $(8.96$ g. ragweed pollen).

\begin{tabular}{|c|c|c|c|c|}
\hline Found: & $\begin{array}{l}\text { Nitrogen. } \\
\text { G. }\end{array}$ & $\begin{array}{c}\text { Nitrogen. } \\
\% .\end{array}$ & $\begin{array}{c}\text { Substance. } \\
\mathrm{G} .\end{array}$ & $\begin{array}{c}\text { Substance } \\
\% .\end{array}$ \\
\hline Water extract. & 0.0680 & 0.75 & . & . \\
\hline Coaguable albumin............ & $0.0149^{3}$ & 0.16 & 0.0934 & 1.04 \\
\hline Proteoses................. & 0.0086 & 0.095 & 0.0538 & 0.60 \\
\hline Phosphotungstic ppt. . . . . . . & 0.0256 & 0.29 & . & . \\
\hline Not ppt. by phosphotungstic..... & 0.0179 & 0.20 & . & . \\
\hline ro\% salt extract. . & 0.0317 & $0.3 I$ & . & . \\
\hline Coagulable protein $\ldots . . . \ldots \ldots$. & $0.0042^{3}$ & 0.05 & 0.0266 & 0.30 \\
\hline Filtrate..................... & 0.0234 & 0.26 & . & $\cdots$ \\
\hline $0.2 \% \mathrm{KOH}$ extract ${ }^{4}$. & . & 0.62 & . & . \\
\hline $\int$ Glutelin. & $0.023^{3}$ & 0.26 & 0.1445 & I.60 \\
\hline | Non-precipitable................ & 0.0322 & 0.36 & .. & . \\
\hline
\end{tabular}

These results are calculated from the following analytical data:

1 . physiol. Chem., 36, 85 (rgor).

2 Ibid., ro, 326 (1886); Ibid., 66, 128 (1910).

${ }^{3}$ Calculated, factor $6^{1 / 4}$.

46 stccessive extractions; but further extractions would yield more. 
7.0 g. was extracted 5 times with distilled water ( + toluene) by shaking an hour each time and then centrifuging to a very complete separation. The combined extracts measured $r_{40} \mathrm{cc}$. This solution was rendered slightly acid by the addition of a few drops of $0.5 \mathrm{~N}$ acetic acid and the albumin separated prettily by coagulation (chieffy at $51-56^{\circ}$ ). This was filtered off on a tared paper, washed with boiling water, with alcohol and ether in the ustal manner. It weighed $0.0934 \mathrm{~g}$. equivalent to $1.04 \%$ of the pollen. This amounts to about $0.165 \%$ nitrogen.

The filtrate and washings were concentrated to $54 \mathrm{cc}$. and saturated by the addition of $25 \mathrm{~g}$. zinc sulfate in the presence of one cc. sulfuric acid ( 1 to 4 ). On standing in the ice chest a flocculent, sticky proteose fraction separated. This was filtered off and washed with acidified saturated zinc sulfate solution. The precipitate was dissolved in hot water and nitrogen determined. The proteose $(0.0538 \mathrm{~g}$.) anounted to $0.6 \%$ of the poilen.

The filtrate $(9 \circ \mathrm{cc}$ ) was diluted by the addition of $45 \mathrm{cc}$. sulfuric acid ( 1 to 4 ) and completely precipitated by the cautious addition of if $\mathrm{cc} .20 \%$ phosphotungstic acid. After standing overnight the precipitate was filtered off and washed separately with $2.5 \%$ phosphotungstic acid in $5 \%$ sulfuric acid. The filtrate and washings were joined, filtered again, and made up to a volume of $250 \mathrm{cc}$.

The washed phosphotungstic precipitates were dissolved in very dilute sodium hydroxide solution, and the volume made up to $500 \mathrm{cc}$. roo $\mathrm{cc}$. required $3.65 \mathrm{ce}$. of o. I $N$ acid, equivalent to 0.005 I I $g$. nitrogen. The phosphotungstate therefore precipitated $0.02555 \mathrm{~g}$. nitrogen, equivalent to $0.29 \%$ of the pollen.

The filtrate from the phosphotungstic precipitate, containing amino acids, ete, was aliquoted and $50 \mathrm{cc} .(1 / 5)$ was made slightly alkalitse, concentrated and digested with $35 \mathrm{cc}$. sulfuric acid and $\mathrm{I}_{5} \mathrm{~g}$. potassium sulfate and $0.25 \mathrm{~g}$. cupric sulfate. This Kjeldahl determination showed the presence of $0.01785 \mathrm{~g}$. nitrogen in this solution; or $0.2 \%$ of the pollen. $50 \mathrm{cc}$. required by the Kjeldahl process $2.55 \mathrm{cc}$. of $0.1 \mathrm{~N}$ acid. To the remaining $4 / 6$ of the above solution sodium hydroxide solution was added until a precipitate of zinc hydroxide resulted. The solution was cleared by the cautious addition of dil. acetic acid, and concentrated to a volume of $95 \mathrm{cc}$.

In order to have some data indicating the quantity of aliphatic amino compounds that might be present in this solution these were determined by the Van Slyke method 10 ce, contains $1.5 \mathrm{mg}$. nitrogen (K jeldahl).

ro ce. gave $x .12 \mathrm{cc} . \mathrm{N}$ at $22^{\circ}$ and $749 \mathrm{~mm}$. Eqquivalent to $0.622 \mathrm{mg}$.

ro cc. gave $\mathrm{x} .2 \mathrm{cc} . \mathrm{N}$ at $2 \mathrm{I}^{\circ}$ and $74^{8} \mathrm{~mm}$. Equivalent to $0.669 \mathrm{mg}$.

From these figures we calculated that about $40 \%$ of the nitrogen is in the free amino group, and it is evident that the substances of the peptid form predominate.

$10 \%$ Saline Extraction.- The residue from the above aqueous extraction was further extracted during the following day with 5 portions of $10 \%$ salt solution. The total extract amounted to $150 \mathrm{cc}$. Upon coagulating this solution. in the presence of a few drops of $0.5 N$ acetic acid $0.0266 \mathrm{~g}$. coagulable protein separated. This is equivalent to $0.3 \%$.

The filtrate from this material was analyzed by the Kjeldahl process, requiring xo.25 ce. O. I $N$ acid, equivalent to $0.01435 \mathrm{~g}$. of nitrogent.

The pollen residue left after the above described 5 extractions with $10 \%$ salt solution, was further extracted with 5 more portions of about $35 \mathrm{cc}$, each. This tenth extract was practically nitrogen free, containing $0.7 \mathrm{mg}$. nitrogen. The sixth to ninth extract inclusive contained $8.4 \mathrm{mg}$. nitrogen. Total nitrogen therefore is $0.0234 \mathrm{~g}$. or $0.26 \%$

Ixtraction with $0.2 \%$ potassium hydroxide was carried out on the residue from the saline extracts. A series of 6 extractions was combined, acidified with acetic acid, and $0.1445 \mathrm{~g}$. glutelin obtained. The filtrate contained $0.0322 \mathrm{~g}$. nitrogen or $0.36 \%$. 
The seventh extract of $100 \mathrm{cc}$. yielded nitrogen equivalent to $0.35 \%$ of the pollen after prolonged standing.

The remainder of the ether and alcohol extracted pollen (439 g.) was now studied with the purpose of $(I)$ preparing the albumin + proteose fraction; (2) separating the albumin from this mixture by coagulation in pure condition and describing it chemically. The biological reactions are best studied with the mixture rather than with a more purified product. An anticipated yield of $1.6 \%$ of $440 \mathrm{~g}$. would be about $7 \mathrm{~g}$.

Albumin.-The remaining ragweed pollen which had been exhausted with ether and with $95 \%$ alcohol $(34 \mathrm{r}$ g.) was macerated 4 times with distilled water and the extracts, filtered off on a Büchner funnel, measured approximately one liter each except the second which was only $500 \mathrm{cc}$. The time used for maceration was one hour each, and small additional quantities of cold water were used to wash the pollen on the Büchner funnel. The first two extracts, which were rather highly tan colored, were precipitated by saturation with ammonium sulfate. The mixture stood in the ice chest overnight and the precipitated albumin and proteose was skimmed off from the surface with a spatula as far as possible. This was dried on a porous plate. A portion of this mixture (I.3 g.) was put aside for the biological study. The ammonium sulfate saturated, fluid "A" was filtered off and such amounts of the albumin and proteose precipitate as could not be removed with a spatula, $i$. $e$., material sticking to the walls of the flask, etc., was separated as completely as possible from the liquid. This precipitate plus the larger quantity skimmed off (except the $\mathrm{r} .3 \mathrm{~g}$. before mentioned) was dissolved in distilled water and a dark colored solution resulted. This was filtered through porcelain, and the albumin was coagulated at $65^{\circ}$ in the presence of a few drops of 0.5 acetic acid. The pollen albumin which separated upon coagulation was removed by the centrifuge, washed 4 times with boiling water, with $50 \%$ alcohol, 95\% alcohol, absolute alcohol and ether. It weighed 1.95 $\mathrm{g}$. The filtrate from this coagulated albumin was used for the preparation of ragweed pollen proteose.

The third and fourth aqueous extracts after filtration through porcelain were coagulated directly at $65^{\circ}(0.5 N$ acetic). The yield was $1.37 \mathrm{~g}$. further. The filtrate from this was worked up for proteose, etc.

After completing the water extractions, four ${ }^{1} 10 \%$ salt extractions were made: upon coagulating at $65^{\circ}$ these yielded $\mathrm{r} .42 \mathrm{~g}$. further; this material is probably the same albumin as was obtained in the water extractions but which failed to be extracted at first. The last saline extract was made with more than 3 liters of solvent, and was allowed to stand for 24 hours. It yielded only a trace of coagulable material.

1 rime of first extract, one hr.; the second stood overnight; the third, one hr.; and the fourth, 24 hrs. 
After separating the albumin coagulating at $65^{\circ}$, the saline filtrate was in every case heated gradually to $100^{\circ}$ and held there for 15 minutes, but there was very little evidence of a globulin with higher coagulating point. In some of the water extracts, a further small amount of albumin was otained by this procedure.

Proteose.-The third and fourth water extracts from which all coagulable protein had been removed were concentrated and saturated with ammonium sulfate and the gummy separation floated on the surface so that the underlying saturated solution could be siphoned off ("B"). In the same manner the proteose was separated from the filtrate from the first yield of coagulable protein from Extractions I and 2. The proteoses were combined, redissolved in water and reprecipitated by saturation with ammonium sulfate. The precipitate was finally dissolved in 50 cc. of water and dialyzed free from sulfate. The dialysate was poured into ro volumes of absolute alcohol, and $4.3 \mathrm{~g}$. proteose was obtained.

The yields are, coagulable albumin $=4.7 \mathrm{~g} .=1.1 \%$; proteose $=$ $4.3 \mathrm{~g} .=1.0 \%$ (exclusive of $\mathrm{r} .3 \mathrm{~g}$. mixture, $0.3 \%$ put aside). Including this we find: albumin $=1.22 \%$; proteose $=1.1 \%$.

Glutelin.-After completely extracting the ragweed pollen as above described a further extraction was made with 1.5 liters of $0.2 \%$ potassium hydroxide solution. This was filtered through porcelain, and slightly acidified with $60 \%$ acetic acid. On standing, $0.36 \mathrm{~g}$. of a yellowish brown protein was obtained in the usual manter. A second extraction with $0.5 \%$ potassium hydroxide ( 3 liters) yielded $7.8 \mathrm{r}$ g. and a third similarly yielded 3.14 g. of a fine, white, dusty powder. The fourth extraction gave I.225 g. and the alkaline extractions were discontinued. The total glutelin fraction amounts to $12.53 \mathrm{~g}$. and was equivalent to $2.9 \%$ of the pollen. It is undoubtedly the chief protein present.

The slightly acid filtrates from the above described preparations of glutelin were concentrated on the steam-bath to a smaller volume and made acid with $5 \%$ sulfuric acid. The total volume equalled $1270 \mathrm{cc}$.

$50 \mathrm{cc}$. required $30.2 \mathrm{cc}, 0.1 N$ acid (Kjeldaht).

The solution contained $1.06 \mathrm{~g}$. nitrogen, but was not further studied.

Second Protein Extraction.-A collection of ragweed pollen (1916), the ether extract of which yielded $89 \mathrm{~g}$. fat, was now used for further study and to obtain larger quantities of the fractions obtained in the first extraction.

$7.7 \times \mathrm{g}$. ether extracted pollen equivalent to $8.0 \mathrm{~g}$. of the original pollen was exanined according to the quantitative methods described on page 673 using $0.8 \%$ saline solution for the extracting medium, instead of water, followed by $10 \%$ saline solution. The coagulated protein weighed $0.18 \mathrm{I}$ g., equivalent to $2.3 \%$. When saturated with zine sulfate, the filtrate from the coagulated protein yielded $0.097 \%$ g. proteose 60.01554 g. nitrogen $\times 6.25$ ). This is equivalent to $1.2 \%$ of the pollen. 
The filtrate, when precipitated with phosphotungstic acid, yielded $0.0555 \mathrm{~g}$. precipitable nitrogen, equivalent to $0.7 \%$. The non-precipitable nitrogen amounted to $0.03665 \mathrm{~g}$., or $0.5 \%$. The yield of non-protein water soluble substances $(\mathrm{r} .2 \%)$ is lower here than previously ${ }^{1}$ found, $x .9 \%$ having been found when extracting the fatfree polles with $10 \%$ saline solution and removing protein and proteose with alcohol.

$400 \mathrm{~g}$. of fat-free material ( $=450 \mathrm{~g}$. pollen) was percolated to exhaustion with cold $95 \%$ alcohol. It was then repercolated with anhydrous ether, and air dried. The alcoholic extract was combined with other similar extracts, which were later separately examined. The residue here weighed $313 \mathrm{~g}$. This now corresponds to material used for the arst protein extraction.

A quantity, $3.13 \mathrm{~g}$. ( $4.5 \mathrm{~g}$. of the original pollen) was analyzed to find out how the alcohol percolation had affected the nitrogen distribution. Found: Coagulable protein, I. $6 \%$; filtrate of coagulable protein $=0.62 \%$ nitrogen. The amount of protein extracted with $0.8 \%$ saline solution is therefore reduced from $2.3 \%$ to $1.6 \%$, while the alcohol dissolves more than half the non-protein nitrogen reducing the percentage from $1.2 \%$ to less than $0.62 \%$.

Extraction B.-A quantity of ragweed pollen (450 g.) after extraction with ether and alcohol was maceratcd 4 times with distilled water, as described before. The first two water extracts were half-saturated by gently stirring in the calculated quantity of ammonium sulfate crystals and the precipitate centrifuged off.

A representative part of this precipitate $(3.4 \mathrm{~g}$.) was removed and readily dried overnight on a porous plate in a vacuum desiccator. The remainder of the material precipitated at half saturation was redissolved in water, filtered through porcelain, and heated at $60^{\circ}$ in the presence of $4 \mathrm{cc}$. $0.5 \mathrm{~N}$ acetic acid. The coagulated albumin obtained weighed $2.78 \mathrm{~g}$.

The filtrate from the coagulum was concentrated to a volume of 180 cc. and filtered clear. A very slight precipitation took place at $1 / 4$ saturation and the separation was practically complete at $1 / 2$ saturation. The proteose was removed by centrifuging, redissolved in water and precipitated by the addition of alcohol. It weighed $0.79 \mathrm{~g}$. At half saturation therefore the precipitate obtained from the water extract is about $78 \%$ albumin and $22 \%$ proteose. The albumin therefore amounts to $1.2 \%$.

The original filtrates from which albumin and proteose had been removed by half saturation were now saturated with powdered ammonium sulfate and the slimy precipitate removed by centrifuging, and redissolved in water. A small quantity $(0.27 \mathrm{~g}$.) failed to redissolve. The solution was concentrated on the steam bath and this caused the separation of $0.26 \mathrm{~g}$. further. These two precipitates were not examined but are probably coagulated albumin. The clear filtrate from these slight separations was made slightly acid with $0.5 N$ acetic acid and boiled on an electric stove but no albumin remained. Saturation of this solution yielded a

1. ThIS JOURNAI, 39, 1473 (1917). 
crop of proteose ( $7.6 \mathrm{~g}$. ammonium sulfate-free). Upon dialysis only $4.65 \mathrm{~g}$. was recovered.

Water Extracts 3 and 4 were passed through porcelain acidified and heated at $65^{\circ}$ for about 20 minutes. Two crops of coagulated albumin separated which weighed $0.28 \mathrm{~g}$. and $0.83 \mathrm{~g}$., respectively.

The filtrates from these coagulated albumin separations were joined and concentrated to $200 \mathrm{cc}$. and saturated with ammonium sulfate. The precipitate was centrifuged off and redissolved in water, when a small quantity $(0.28 \mathrm{~g}$.) remained insoluble. The proteose was reprecipitated by saturation with ammonium sulfate and then with alcohol. It weighed $0.9 \mathrm{~g}$. free from ammonium sulfate. The several ammonium sulfate saturated filtrates were put aside for further study as before.

After completing the water extractions above described, 4 extractions were made with ro\% salt solution but the quantities isolated were insignificant. Coagulation of 2,3 and 4 at $100^{\circ}$ yielded only $0.12 \mathrm{~g}$. The first salt extract was treated separately and a preparation of the material separating at half saturation with ammonium sulfate was made. It was quite small.

From the weights above recorded we find a total yield of albumin $1.5 \%$, proteose $=2.2 \%$.

The glutelin was extracted in 4 fractions amounting, respectively, to 2.02 , $4.0,2.62$ and $4.45 \mathrm{~g}$. This is $13.09 \mathrm{~g}$. equivalent to $2.9 \%$.

Third Protein Extraction.-A quantity of ragweed pollen (26I g.) was exhausted with ether and then with $95 \%$ alcohol. The material was then extracted twice with sterile distilled water the time of each extraction being about eight hours. The first filtrate amounted to 1200 cc. and the second to about goo cc. These were united and half saturated with ammonium sulfate, and the protein + proteose precipitate separated by centrifuging. The precipitate was washed with half-saturated ammonium sulfate solution and redissolved in distilled water. A slight amount of insoluble material was filtered off and the clear fiuid was dialyzed against running distilled water for about $5 \frac{1}{2}$ days. The contents of the parchment bag was centrifuged and $0.28 \mathrm{~g}$. of material removed. This material was a light brown powder and was essentially an alteration product. It was mechanically shaken with distilled water, and the solvent decanted after centrifuging. It was then shaken with $10 \%$ saline solution and this yielded only $0.020 \mathrm{~g}$. on coagulation, so that at most a trace $(0.01 \%)$ of globulin is present. The dry extracted residue still weighed $0.2 \mathrm{I} \mathrm{g}$. after these operations.

The water solution of albumin and proteoses was filtered through a diatomaceous filter and then divided into two unequal parts $(5 \mathrm{IO} \mathrm{cc}$. and $\mathrm{r}_{50} \mathrm{cc}$.). The former volume, representing about $200 \mathrm{~g}$. pollen, was coagulated in the presence of 5 cc. $0.5 \mathrm{~N}$ acetic acid. Coagulation 
began even below $47-48^{\circ}$ and appeared to be complete before $54^{\circ}$ was attained. The heating was continued for $20-30$ minutes at $60^{\circ}$ and the coagulated albumin removed in the usual manner. It weighed $2.0 \mathrm{~g}$. equivalent to $1.0 \%$ of the pollen taken.

The filtrate from the coagulated albumin was concentrated on the steam bath. A slight further separation of coagulum was filtered off and the solution brought to a voltime of $\mathrm{ro} \mathrm{cc}$. The proteose was precipitated with alcohol. It amounted to $0.73 \mathrm{~g}$.

The $150 \mathrm{cc}$. volume representing about $60 \mathrm{~g}$. pollen was precipitated with absolute alcohol $(430 \mathrm{cc}$.) in the manner used in preparing pollen vaccine. A flocculent precipitate came down, which was removed by centrifuging and the filtrate yielded only a trace more on standing overnight, and further addition of absolute alcohol gave no appreciable increase. The precipitate was washed with alcohol of the concentration at which it had been precipitated with absolute alcohol, with ether, and put aside for biological study.

The half saturated solutions from which the above described products had been removed were now completely saturated and an oily, smeary proteose came down. It was removed by centrifuging, reprecipitated from solution with alcohol, and, collected in the usual manner, it weighed I $3.67 \mathrm{~g}$. , and contained a considerable amount of ammonium sulfate. The proteose precipitating at $5 /$ ro to $10 /$ Io is the chief protein constituent of the water extract, as shown in extraction "B." This material was further purified by redissolving, concentrating to remove a small quantity of albumin which is probably present, and then removing the sulfate with barium hydroxide, and finally again concentrating to dryness. This method obviates the loss occurring in dialysis. It weighed $6.77 \mathrm{~g}$., equivalent to $2.6 \%$.

After extracting the pollen with distilled water as described, a large volume (21.) of 10\% salt was shaken with it for 24 . hours. This extract upon coagulating at $100^{\circ}$ gave $0.55 \mathrm{~g}$. coagulated albumin. After these, two further extractions were made with one liter of $0.2 \%$ and 2 liters of $1.0 \%$ sodium hydroxide solutions. These yielded, respectively, I. 7 , and $1.8 \mathrm{~g}$. glutelin. The work on the sample was then discontinued.

The yields were albumin, $1.0 \%$; proteose, $2 /$ ro to $5 /$ ro saturated, $0.4 \%$; proteose, $5 /$ io to ro/ro saturated, $2.6 \%$.

\section{Composition of Ragweed Pollen Proteins.}

The Coagulated Albumin.- The first sample prepared (x.95 g.) was not satisfactory for analytical purposes, and the second $(2.78 \mathrm{~g}$.) was light yellow in color. The analytical character of this product could be accurately determined on the third preparation (2.0 g.) which was exceedingiy pure and practically colorless. It was ashiess.

Moisture, to.6, 10.3. Dried at $11^{\circ}: \mathrm{C}, 53.8 ; \mathrm{H} .7 .2 ; \mathrm{N}, \mathrm{I} 5.2 ; \mathrm{S}, \mathrm{I} .3 ; \mathrm{P}$, absent. 
The Glutelin.-The fine, almost white, dusty powder, after drying in a vacuum desiccator over sulfuric acid, was analyzed. For the combustion, a chromate tube and reduced gauze were used.

Sample I, 2 (7.8I g.). Moisture, 20.7, 21.0. Ash, 4.28. Dried at $110^{\circ}$, and calculated ash free: $\mathrm{C}, 54.9 ; \mathrm{H}, 6.9 ; \mathrm{N}, \mathrm{I} 3.85$.

Sample II, 4 (4.45 g.): C, $55.0 ; \mathrm{H}, 7.2$,

The proteoses which were divided into two classes, $i_{0} e_{0}$, those precipitated at half saturation and those requiring $5 / 10$ to 10/10 saturation, were not analyzed, as we were dealing with mixtures.

\section{Production of Experimental Anaphylaxis.}

It is held by some that anaphylaxis cannot be produced with pollen extracts, but there is no question about the positive results obtained when correct quantities are properly given. Using amounts similar to those used by Wells and Osborne ${ }^{2}$ when studying the anaphylactogenic activity of proteins and proteoses typical reactions result.

A few reactions carried out by Mr. Wilbur Payne are recorded below. The material used was that precipitated in the first protein extraction by saturating the aqueous extract with ammonium sulfate $(73 \%$ albumin + proteose, $\left.27 \%\left(\mathrm{NH}_{4}\right)_{2} \mathrm{SO}_{4}\right)$.

Expt. I. A guinea pig ( $398 \mathrm{~g}$.) was given a sensitizing dose of ro $\mathrm{mg}$. in $0.67 \mathrm{cc}$. water. After I8 days a second intraperitoneal injection of $50 \mathrm{mg}$. was given. The reaction was slight or negative.

Expt. II. A guinea pig $(4 \times \mathrm{O}$.) was given a first dose of $15 \mathrm{mg}$. in one cc. After 20 days the animal was reinjected with an intoxicating dose of $150 \mathrm{mg}$. It was partially paralyzed in 7 minutes, unable to stand after one hr. and dead in $\mathrm{r}^{3} / \mathrm{a}$ hours.

Expt. III. A pig (440 g.) was sensitized with Io ming. and after 19 days reinjected with $100 \mathrm{mg}$. A severe reaction resulted in a paralysis of the hind quarters in $15 \mathrm{~min}$, inability to stand in $30 \mathrm{~min}$, and death in $\mathrm{I}^{1 / 2} \mathrm{hrs}$.

Whether the proteose increases the anaphylactic power of the native albumin has not been studied. The writer does not believe that these proteins which form such a conspicuous part of the soluble nitrogenous substances are hydrolytic cleavage products of the albumin. They, like the seed proteoses, will probably be found to have anaphylactogenic properties.

Examination of Protein and Proteose-Free Water and Saline Extracts.

The by-products of the aqueous extractions of $x r_{50} \mathrm{~g}$. pollen above described consisted of solutions saturated with ammonium sulfate. The latter was completely removed with barium hydroxide and the barium quantitatively with sulfuric acid. After concentrating to a volume of about one liter, clarifying with basic lead acetate and removing the excess of lead with hydrogen sulfide, the base fraction was precipitated in the usual manner with phosphotungstic acid.

1 Cooke, Flood and Coca, $J$. Immunol., 2, 217 (1917).

2. J. Infect. Diseases, $14,364,377$ (1914); 17,259 (x915); x9, 183 (1916). 
The purine fraction, precipitated with silver nitrate could be divided into two parts; (a) soluble in ammonia, (b) purine fraction. The part soluble in ammonia appeared to be the silver salt of guanosine. The silver salt was decomposed with hydrogen sulfide and the free base when distilled with hydrochloric acid yielded phloroglucide equivalent to o.or7 g. pentose which corresponds to 0.032 guanosine. The solution from which the furfural had been distilled was evaporated to dryness and the guanine precipitated with ammoniacal silver nitrate solution, and then again liberated with hydrogen sulfide. The free base gave all the qualitative tests lists for guanine.

The systematic examination of (b) yielded $0.3 \mathrm{~g}$. of adenine picrate, m. p. $279-28 \mathrm{I}^{\circ}$.

Calc. for $\mathrm{C}_{5} \mathrm{H}_{5} \mathrm{~N}_{5}, \mathrm{C}_{6} \mathrm{H}_{3} \mathrm{~N}_{3} \mathrm{O}_{7}: \mathrm{C}, 36.25 ; \mathrm{H}, 2.2$, Found: $\mathrm{C}, 36.6 ; \mathrm{H}, 2.55$.

The filtrate from the purine silver was now examined by the method of Kossel and Patten. There was found; histidine, $0.09 \%$; arginine, $0.01 \%$; lysine, $0.05 \%$ and agmantine, approximately $0.05 \%$.

The histidine was identified as picrolonate which decomposed at about $224^{\circ}$.

Calc. for $\mathrm{C}_{6} \mathrm{H}_{8} \mathrm{~N}_{8} \mathrm{O}_{2} . \mathrm{C}_{10} \mathrm{H}_{8} \mathrm{~N}_{4} \mathrm{O}_{8}: \mathrm{C}, 45.8 ; \mathrm{H}, 4 . x$. Found: $\mathrm{C}, 45.2 ; \mathrm{H}, 4.55$.

The arginine picrolonate decomposed very sharply at $232^{\circ}$.

Calc. for $\mathrm{C}_{6} \mathrm{H}_{14} \mathrm{~N}_{4} \mathrm{O}_{2} . \mathrm{C}_{10} \mathrm{H}_{8} \mathrm{~N}_{4} \mathrm{O}_{5}: \mathrm{C}, 43.8 ; \mathrm{H}, 5.05$. Found: $\mathrm{C}, 43.8 ; \mathrm{H}, 5.2$.

Lysine picrate gave the following analysis:

Calc. for $\mathrm{C}_{6} \mathrm{H}_{14} \mathrm{~N}_{2} \mathrm{O}_{2} \mathrm{C}_{8} \mathrm{H}_{3} \mathrm{~N}_{3} \mathrm{O}_{7} ; \mathrm{C}, 38.4 ; \mathrm{H}, 4.55$. Found: $\mathrm{C}, 38.8 ; \mathrm{H}, 4.96$.

Agmantine picrate crystallized out first upon fractionally crystallizing the lysine picrate fraction. It separated in crusts. On slow heating it decomposes at $235^{-2} 40^{\circ}$.

Calc. for $\mathrm{C}_{6} \mathrm{H}_{14} \mathrm{~N}_{4} .2 \mathrm{C}_{6} \mathrm{H}_{3} \mathrm{O}_{7} \mathrm{~N}_{8}: \mathrm{C}, 34.7 ; \mathrm{H}, 3.4$. Found: $\mathrm{C}, 34.4 ; \mathrm{H}, 3.4$. The picric acid extract gave, $\mathrm{C}_{6} \mathrm{H}_{3} \mathrm{O}_{7} \mathrm{~N}_{8}=77.9 \%$; Calc., $77.9 \%$.

The free base was converted into the gold salt which decomposed at $220-223^{\circ}$

Cale. for $\mathrm{C}_{6} \mathrm{H}_{44} \mathrm{~N}_{4} .2 \mathrm{HAuCl}_{4}: \mathrm{Au}, 48.7$. Found: 49.4 .

Examination of Substances not Precipitable with Phosphotungstic Acid.

The preliminary examination of this fraction on the $10 \%$ saline extracts of $440 \mathrm{~g}$. showed that a large proportion $(\mathrm{r} / 25)$ of the nitrogen was present in the amino form but owing to the failure of copper salts to separate, ${ }^{1}$ the remainder of the material was examined for amino acids by the ester process.

1 The solution was concentrated and most of the remaining sodium chloride was removed by digesting the concentrated residue with alcohol and filtering. From the filtrate alcohol was removed and the solution was concentrated to a volume of about $35 \mathrm{cc}$. This solution was strongly acid. A test portion (about $5 \mathrm{cc}$.) was rendered very slightly alkaline with sodium hydroxide and then slightly acid with $0.5 N$ acetic acid. When a solution of mercuric nitrate in dil. nitric acid was added there resulted a gradual but slight white precipitate indicating the presence of one or more of the fol- 
The main filtrate from the phosphotungstic precipitate was freed from this acid with barium hydroxide and then the latter was quantitatively removed with sulfuric acid. The solution was concentrated at $35^{\circ}$ in a vacuum to a volume of $15 \mathrm{cc}$. Although absolutely free from sulfuric acid or barium ions no crystallization could be effected. The solution was saturated at $0^{\circ}$ with hydrochloric acid and a separation of sodium and potassium chloride resulted. The filtrate from this was taken to dryness and water removed by repeated evaporation with absolute al cohol. The residue was dissolved in roo cc. of $1.5 \%$ alcoholic hydrochloric acid and esterified by the method of Phelps and Phelps. The esters were shaken out at low temperatures with ether as in the Fischer process, and a second esterification carried out on the residue. No amino esters were found, the total nitrogen in the ether extracted amounting to only $0.32 \mathrm{~g}$.

\section{Summary.}

Pollen of the Ragweed (Ambrosia artemisifolia L.) has been examined for the purpose of isolating the proteins. The pollen was percolated with ether, and with cold $95 \%$ alcohol, and then with water, saline solution, and dilute alkali. By this process the yield of protein is not materially decreased, but the nitrogen extracted with cold alcohol is probably less than the quantity found in a hot alcoholic extract. (1.08\%.)

From the water extracts, an albumin coagulating at low temperatures $\left(45-50^{\circ}\right)$ was found to be present to the extent of $1.2 \%$, while proteoses predominated. $(3 \%$.) Precipitation of this fraction by half saturation with ammonium sulfate gives a product consisting of $3 / 4$ albumin and $1 / 4$ proteose and possessing anaphylactogenic properties.

After saturating the aqueous extract of pollen with ammonium sulfate, the protein-free solution after removal of ammonium sulfate yield is peptone adenine, guanosine (?), histidine, arginine, lysine and agmantine. After. precipitation of the above mentioned bases with phosphotungstic acid, the absence of amino acids in the filtrate was demonstrated.

The chief protein is a glutelin extracted with dilute alkalies.

To Mr. Clayre Pomeroy the writer is indebted for skillful assistance in carrying out this work.

Kal,amazoo, Mich.

lowing substances: asparagine, glutamine, allantoine, or possibly tyrosine. A test ( 2 cc.) with Millon's reagent was positive. Pauly's test $(2$ cc.) was brilliantly positive. Another portion of the solution gave a negative tryptophane test. When a slightly alkaline $(3 \mathrm{cc}$ ) test portion was boiled with freshly precipitated copper hydroxide a deep biue solution resulted. When this blue solution was boiled and $0.1 N$ alkali added, we obtained the positive test for the presence of amino acids as described by Kober (J.Biol. Chem., I0, 9 (19I 1 )) and a negative test as to peptids.

The main part of the solution $(20 \mathrm{cc})$. was boiled with an excess of copper hydroxide, filtered and the solution of the copper salts concentrated to about $35 \mathrm{cc}$, but we were unsuccessful in obtaining copper salts of the amino acids to separate. 